\title{
Utilization of delivery services in the context of Prevention of HIV from Mother- To-Child (PMTCT) in a rural community, South Africa
}

\author{
K Peltzer \\ Human Sciences Research Council \& University of Limpopo
}

T Mosala

Human Sciences Research Council

O Shisana

Human Sciences Research Council

A Nqeteko

Human Sciences Research Council

\section{Keywords:}

Utilization, access, delivery services, pregnant women, HIV/AIDS, resource poor, rural South Africa

\section{Correspondence address:}

Prof Karl Peltzer

Social Aspects of HIV/AIDS and Health

Human Sciences Research Council

Private Bag X41

Pretoria 0001

South Africa

Tel.: (015) 302-2637

Email:peltzerk@hsrc.ac.za

\section{Abstract: Curationis 29(1): 54-61}

The aim of this study was to investigate the utilization of delivery services in the context of PMTCT in a rural community in South Africa. Based on a cross-sectional survey, the sample included 870 pregnant women who had delivered before recruited from five PMTCT clinics and surrounding communities. Results indicated that $55.9 \%$ had delivered their last child in a health care facility and $44.1 \%$ at home (mostly without assistance from a traditional birth attendant). The odds of access to the health facility were (1) women who stayed close to the hospital $(\mathrm{OR}=2.87),(2)$ those who had higher formal education $(\mathrm{OR}=1.55)$, (3) higher traveling costs (affordability) to get to nearest clinic $(\mathrm{OR}=1.77)$, and (4) those who were single $(\mathrm{OR}=1.58)$. Childbirth experiences of the mother or mother-in-law greatly influenced the delivery choices in terms of home delivery. The majority of the pregnant women were aware of mother-to-child HIV transmission but only $9 \%$ of the pregnant women had ever been tested for HIV. HIV knowledge, HIV testing behaviour and attitudes were found to be not associated with the delivery option.

\section{Introduction}

Lack of access to maternal health services resulted in poor utilization of health services by rural communities. The rate of home deliveries ranged from $40 \%$ to $92 \%$ in rural South Africa (Tsoka, Sueur \& Sharp 2003:70). For example, O'Mahony and Steinberg (1995) conducted a survey of two hundred women on place of delivery, home delivery practices and antenatal care for the most recent delivery (within the previous 5 years) from randomly selected clusters, obtained from a multistage random sampling process, in rural Transkei (Eastem Cape including both former Transkei and Ciskei, and South Africa). Two-thirds had delivered at home (home-based) and onethird within the health services (settingbased). Of those who delivered at home $62(47 \%)$ were alone at the time of delivery while the remainder were assisted by a close relative or neighbour; $38 \%$ had one or more risk factors for obstetric complications. Uyirwoth, Itsweng, Mpai, Nchabeleng and Nkoane (1996: 91) found in a rural community in the Limpopo Province among mothers who delivered 
within 12 months before the date of interview that the proportion of health facility deliveries was $74.6 \%$ while $26.3 \%$ of all births occurred at home. Inaccessibility to maternity services, lack of money, negative staff attitudes and lack of privacy were the common reasons given for preference of home delivery. Accessibility factors (cost, distance, transport, availability of health facilities, and nurses' attitudes) were also major barriers, whereas traditional beliefs were reported as less significant, in a study in Northern Ghana (Mills \& Bertrand, 2005:45). Other studies found that the attitudes of mothers or mother-in-laws and social influence from the spouse played a role in the delivery options (Amooti-Kaguna \& Nuwaha 2000:203; Duong et al. 2005: 172).

Since the implementation of free maternity services for pregnant women and children under six years of age in 1994 in South Africa, McCoy (1996:5) noted that although more maternity services were provided in rural areas, they were still inaccessible to many women.

Use of skilled professional childbirth attendants by all women remains a goal of safe motherhood programmes, despite well-known barriers. Increasing use of skilled professional childbirth attendants, facility-based when feasible, should also be a behavioural goal of PMTCT programmes. This would allow timely, supervised receipt of ARVs during the intrapartum period. while at the same time allowing opportunity for quality routine childbirth care, and improved obstetric practice administered by skilled providers (Moore 2003: 4). However, partly due to the magnitude of MTCT and the urgency of increasing coverage of PMTCT interventions, and taking into account the childbirth realities in much of rural Africa, many programmes have begun to focus efforts on improving obstetric practices among traditional birth attendants (TBAs) during home-based childbirth. Challenging global consensus on the diminishing need for and role of TBAs, some PMTCT programmes have placed TBAs at the center of efforts to reduce MTCT in the community. For the most part. this includes reinforcing quality home-based maternity care by TBAs and other family birth attendants and avoidance of home birth practices that could increase MTCT (Moore 2003: 6). The aim of this study was to investigate the utilization of delivery services in the context of PMTCT in a rural community in South Africa.

\section{Method}

\section{Design and setting}

A cross-sectional sample of pregnant women recruited from primary health care clinics (with PMTCT) and from the community. In addition, mothers or mothers-in-law and husbands or partners of the pregnant women were recruited into the study.

The study was conducted in region $\mathrm{E}$, Qaukeni District, in the Eastern Cape. The communities in region $\mathrm{E}$ are rated among the most economically disadvantaged and with relatively poor access to services with less than $50 \%$ having access to basic water supply and basic sanitation. The area is also lagging behind in economic development. It has the highest unemployment rate in the country $(48.5 \%)$. Most employed men work as migrants in Gauteng, Western Cape Province and KwaZulu-Natal. The poverty rate (percentage of population in poverty) was estimated at $63.3 \%$, the second highest in the country. The Human Development Index for the Eastern Cape was 0.51 in 1999. This is far lower than the rest of South Africa, with the exception of the Limpopo Province. The predominant housing type is a traditional mud-and-stick hut, with people living in dispersed homesteads. It has a population density of 39 persons per square kilometre, far below that of Gauteng (385) and KwaZulu-Natal (100) (Mahlalela, Rohde, Meidany, Hutchinson \& Bennett 2001:3-5; RSA National Treasury 2001:2-3). Maternal health services in the study area are rendered by two hospitals (Holy Cross, St Elizabeth), five fixed clinics and a few mobile clinics.

\section{Sample and procedure}

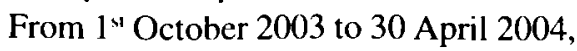
1534 pregnant women were recruited at first antenatal care visit from five clinics implementing PMTCT (61\%) and from five communities around the five clinic areas $(39 \%)$ in region E, Eastern Cape. In addition, the mothers or mothers-in-law $(70.9 \%)$ and husbands or partners $(58.2 \%)$ of the pregnant women were interviewed in their homes. Recruitment of pregnant women in the clinics was done by retired nurses (one per clinic) and recruitment of pregnant women in the community and follow-up of their relatives was done by volunteer community workers (trained in PMTCT community mobilization) from the respective five communities. Both retired nurses and volunteer community workers were trained by the research team in interview-administration of the questionnaire. The recruitment of pregnant women in the community utilized a community mobilization of PMTCT approach. Volunteer community workers held PMTCT awareness meetings in public places and recruited pregnant women (inclusion criteria of not having attended antenatal care with the current pregnancy) by going from house to house in the respective communities. From the total of 1534 pregnant women recruited at first antenatal care visit, in this paper based on the analysis of the questionnaires only pregnant women who had delivered before $(n=903)$ and had indicated the birth place of their last born $(n=870)$ in the interview were included.

The study was approved by the Rhodes University Ethics Committee. The field workers (retired nurses and volunteer community workers from the study communities) obtained informed consent (by explaining the purpose of the study and obtaining a signature) from each pregnant woman willing to participate in the research. Further permission was obtained from the pregnant woman to conduct a home visit for an interview with her mother or mother-in-law and husband or partner; from whom informed consent were obtained likewise. Anonymity and confidentiality of these women were assured. No names and contact details appeared on the questionnaires, codes and identifying information were kept in a separate looked up place. Participants were interviewed in Xhosa (the major language in the target area) with a semistructured questionnaire by trained field workers. The questionnaire had been translated from English into Xhosa. The translation was checked by two external bilingual experts.

\section{Measure}

A questionnaire was developed from the literature (Amooti-Kaguna \& Nawaha 2000:205; Celik \& Hotchkiss 2000:1800; Peltzer et al. 2005:5-6) including the following sections containing both closed and open-ended questions for:

A) the pregnant woman: demographic and socioeconomic data ( 9 items), access to health facility (4 items), pregnancy and delivery related 


\begin{tabular}{|c|c|c|}
\hline $\begin{array}{l}\text { Items } \\
\text { Age: pregnant women (range 15-53 yrs); }(<20 \mathrm{yrs}, 8 \% \text { ) } \\
\text { Number of dependents } \\
\text { Number of natural children }\end{array}$ & $\begin{array}{l}\mathbf{M} \\
\mathbf{N} \\
29.3 \mathrm{yrs} \\
6.4 \\
2.8\end{array}$ & $\begin{array}{l}\text { SD } \\
\% \\
6.9 \text { yrs } \\
3.5 \\
1.9\end{array}$ \\
\hline $\begin{array}{l}\text { Ethnicity } \\
\text { Xhosa } \\
\text { Zulu and other }\end{array}$ & $\begin{array}{l}828 \\
26\end{array}$ & $\begin{array}{l}97.0 \\
3.0\end{array}$ \\
\hline $\begin{array}{l}\text { Education levels } \\
\text { No schooling } \\
\text { Grade } 1-4 \\
\text { Grade } 5-8 \\
\text { Grade } 9-12 \\
\text { Diploma/university }\end{array}$ & $\begin{array}{l}91 \\
240 \\
390 \\
133 \\
13\end{array}$ & $\begin{array}{l}10.5 \\
27.7 \\
45.0 \\
15.3 \\
1.5\end{array}$ \\
\hline $\begin{array}{l}\text { Type of house } \\
\text { Brick house } \\
\text { Other house (traditional) }\end{array}$ & $\begin{array}{l}214 \\
643\end{array}$ & $\begin{array}{l}25.0 \\
75.0\end{array}$ \\
\hline $\begin{array}{l}\text { Marital status } \\
\text { Married } \\
\text { Co-habiting } \\
\text { Widowed } \\
\text { Divorced or separated } \\
\text { Never married }\end{array}$ & $\begin{array}{l}445 \\
24 \\
27 \\
10 \\
359\end{array}$ & $\begin{array}{l}50.9 \\
2.8 \\
3.1 \\
1.2 \\
41.5\end{array}$ \\
\hline $\begin{array}{l}\text { With whom do you live? } \\
\text { Parents } \\
\text { Partner/husband } \\
\text { Siblings } \\
\text { In-laws }\end{array}$ & $\begin{array}{l}352 \\
295 \\
235 \\
140\end{array}$ & $\begin{array}{l}40.5 \\
33.9 \\
27.0 \\
16.1\end{array}$ \\
\hline $\begin{array}{l}\text { Employment } \\
\text { Unemployed } \\
\text { FulV/part/self-employed } \\
\text { Students }\end{array}$ & $\begin{array}{l}730 \\
114 \\
13\end{array}$ & $\begin{array}{l}84.5 \\
14.0 \\
1.5\end{array}$ \\
\hline
\end{tabular}

questions ( 6 items), and HIV knowledge, HIV testing behaviour and attitudes $(8$ items, Cronbach alpha was .58);

B) the mother or mother-in-law: demographic information (4 items), own and daughter's delivery related questions (4 items), HIV knowledge and HIV testing attitudes (6 items, Cronbach alpha was .72);

C) the husband or partner: demographic information (4 items), wife's/partner's delivery related questions (4 items), HIV knowledge, HIV testing behaviour and attitudes $(8$ items, Cronbach alpha was .65)

\section{Data analysis}

Descriptive statistics were calculated using SPSS package (version 12.0). Chisquare tests were used to compare the home-and setting-based groups. Multivariate logistic analysis was conducted to examine the relationships between delivery option and independent variables.

\section{Results}

\section{Sample characteristics}

Almost all of the pregnant women were Xhosa by ethnicity $(97 \%)$. The mean age of pregnant women was 29.3 years ( $\mathrm{SD}=6.9$ years), with a range of 15 to 53 years and $8 \% 19$ years and younger. On average the pregnant women had 2.8 natural children and 6.4 dependents. The majority of the pregnant women were married or cohabitating $(54.7 \%)$ and $41.5 \%$ were never married. Two in five pregnant women were living with their parents, $34 \%$ with their partner or husband and $14 \%$ with their in-laws. Eleven percent of the women had no formal education, $45 \%$ had Grade 5 to 8 , and $28 \%$ had Grade 1 to 4 formal education. Three-quarters lived in a traditional African house while onequarter lived in a brick house. Only a few of the women $(14 \%)$ were formally employed (see Table 1).

\section{Delivery options}

From the 870 pregnant women and mothers, $55.3 \%$ had delivered their last child in a hospital, $0.6 \%$ in a clinic and $44.1 \%$ at home; from those who delivered 


\begin{tabular}{|l|l|l|l|c|}
\hline Place of delivery & $\mathbf{N}$ & $\boldsymbol{\%}$ & Delivered in & \% \\
\hline Hospital & 481 & 55.3 & Hospital or clinic & 55.9 \\
\hline Clinic & 5 & 0.6 & & \\
\cline { 1 - 3 } Home with TBA & 146 & 16.8 & Home (with or with no TBA) & 44.1 \\
\cline { 1 - 3 } Home without TBA & 238 & 27.4 & & \\
\hline
\end{tabular}

intention (see Table 4).

\section{Logistic regression}

We explored the relationship between delivery options (in the past) and independent variables including intention to deliver, mother or mother-in-law's delivery practice with last born, mother or

at home $38 \%$ were assisted by a traditional birth attendant (TBA) and 62\% delivered without a TBA (see Table 2).

The analysis of the comparison between pregnant women who had delivered their last child at home (home-based) or in a health facility (setting-based), found in terms of sociodemographic variables that more younger women, with higher educational levels, higher economic levels (regarding the type of house), being single and having the first child had delivered their last child in a health facility, and in terms of access to health facility pregnant women with longer time periods to get to the nearest health facility (clinic and hospital), having less money for transport to get to the health facility and having no access to telephone were more likely to have delivered their last child at home. The maternal age among the home-based group ( $\mathrm{M}=30.6)$ was higher than among the settings-based group $(M=28.3)(t=496, p<.001)($ see Table 3).

\section{Logistic regression analysis}

Multiple regression allows us to find the best fitting and most parsimonious model to describe the relationship between the dependent variable and a set of independent or predictor variables (Munro \& Page 1993: 229).

We explored the relationship between delivery options and independent variables such as age, education, economic status (dwelling type), number of children, marital status, average travel time to nearest clinic, average travel time to nearest hospital, costs to get to the nearest clinic and access to telephone. Stepwise logistic regression analysis resulted in four significant factors for health facility delivery, namely nearer distance to the nearest hospital $(\mathrm{OR}=2.87,95 \% \mathrm{CI}=1.93-4.27)$, higher education $(\mathrm{OR}=1.55 ; 95 \% \mathrm{CI}=1.26-1.91)$, higher traveling costs (affordability) to get to nearest clinic $(\mathrm{OR}=1.77$; $95 \% \mathrm{Cl}=1.33-2.34)$, and being single $(\mathrm{OR}=1.58,95 \% \mathrm{Cl}=1.07-2.34)$.
On an open-ended question participants were asked about "What assistance can be given to you to assist in prenatal care and delivery?" Most $(982,66.3 \%)$ indicated that they wanted money for the bus fare and some wanted better ambulatory services for delivery (273, $18.4 \%$ ) and transport availability of taxis and buses $(210,14.2 \%)$.

Further, pregnant women were asked who is supporting them during the pregnancy. Comparing home-based and settingsbased delivery, the supporting mother $(199,65 \%)$ was most associated with health facility delivery of the last born, followed by the TBA $(19,57.6 \%)$, husband or partner $(271,54.7 \%)$, and health worker $(13,52 \%)$, while the supporting mother-in-law $(93,60 \%)$ was associated with home delivery of the last born.

\section{Delivery intentions}

When pregnant women were asked about where they intend to deliver their baby, most $(93.7 \%)$ indicated in the health facility and $6.3 \%$ preferred to deliver at home. There seems to be a large difference between $44 \%$ home delivery with the last child and the intention to deliver at home of $6 \%$ with the current pregnancy. Although almost two-thirds (63\%) of the mothers or mother-in-laws of the pregnant women indicated that they had delivered their last born child at home, almost all of them (97\%) wished that their daughter would deliver in a health facility. Likewise almost all the partners or husbands $(97 \%)$ of the participants also indicated that they wished their partner of wife to deliver the current pregnancy in a health facility. Major reasons for the intention to deliver in a health facility mentioned by mothers, in-laws and partners were the belief in good health care from a doctor or nurse and to avoid complications. Comparing pregnant women who had delivered their last child at home or in a health facility, past home delivery of one self, home delivery of the mother or in-law, mother or in-laws and partner or husbands mother-in-law's intention to deliver pregnancy and partner or husband's intention to deliver pregnancy. Stepwise logistic regression analysis resulted in two significant factors for home delivery, mother or mother-in-law delivered her last born at home $(\mathrm{OR}=3.19 ; 95 \% \mathrm{CI}=2.01-5.08)$ and pregnant woman's intention to deliver at home $(\mathrm{OR}=22.91$; $95 \% \mathrm{CI}=2.96-177.47)$; for the latter the sample size was too small.

\section{HIV/AIDS knowledge and HIV testing}

The majority of the pregnant women (81\%), mothers or mother-in-laws (74\%) and partiers or husbands (74\%) knew that a pregnant woman infected with HIV or AIDS can transmit the virus to her unborn child. Only $9 \%$ of the pregnant women and $13 \%$ of their partners or husbands ever had an HIV test. Major barriers of pregnant women for not having had an HIV test were fear of being HIV positive, not aware where to get tested and unsure if the test results will remain confidential. Having been provided with HIV/AIDS information, wanting to know their HIV status and concern for the transmission of HIV from mother to the unborn child were given as major factors that would encourage them to go for an HIV test. Further, almost all mothers or mother-in-laws and partners or husbands of the pregnant women would, however, encourage their daughter or wife to have an HIV test done. HIV knowledge, HIV testing behaviour and attitudes were found to be not associated with the delivery option (home-based or setting-based). Having had contact with an HIV community worker was significantly related with home delivery (see Table 5).

\section{Discussion}

The study found among this rural sample of pregnant women who had delivered before that $55.3 \%$ had delivered their last child in a hospital, $0.6 \%$ in a clinic and 
Table 3: Sociodemographic and access variables by home-based and setting-based delivery groups

\begin{tabular}{|c|c|c|c|}
\hline Variables & $\begin{array}{l}\text { Home-based } \\
\mathrm{n}=\mathbf{3 8 4} \\
(\%)\end{array}$ & $\begin{array}{l}\text { Setting-based } \\
\mathbf{n}=\mathbf{4 8 6} \\
(\%)\end{array}$ & $\chi^{2}$ \\
\hline $\begin{array}{l}\text { Maternal age (years) } \\
15-20 \\
21-30 \\
31-40 \\
41-50\end{array}$ & $\begin{array}{l}4.7 \\
48.0 \\
40.5 \\
6.8\end{array}$ & $\begin{array}{l}9.7 \\
56.0 \\
29.3 \\
5.0\end{array}$ & $18.71^{* * *}$ \\
\hline $\begin{array}{l}\text { Education levels } \\
\text { No schooling } \\
\text { Grade 1-4 } \\
\text { Grade 5-8 } \\
\text { Grade 9-12 } \\
\text { Diploma/university }\end{array}$ & $\begin{array}{l}14.7 \\
35.6 \\
41.6 \\
7.9 \\
0.3\end{array}$ & $\begin{array}{l}7.2 \\
21.4 \\
47.6 \\
21.2 \\
2.5\end{array}$ & $60.40^{* * *}$ \\
\hline $\begin{array}{l}\text { Type of house } \\
\text { Brick house } \\
\text { Other house (traditional) }\end{array}$ & $\begin{array}{l}35.5 \\
47.0\end{array}$ & $\begin{array}{l}64.5 \\
53.0\end{array}$ & $8.54^{* *}$ \\
\hline $\begin{array}{l}\text { Marital status } \\
\text { Never married }(\mathrm{n}=359,41.5 \%) \\
\text { Married/co-habiting/ Separated/ } \\
\text { divorced/widowed }(\mathrm{n}=506,58.5 \% \text { ) }\end{array}$ & $\begin{array}{l}34.5 \\
51.0\end{array}$ & $\begin{array}{l}65.5 \\
49.0\end{array}$ & $23.04^{* * *}$ \\
\hline $\begin{array}{l}\text { Number of children } \\
\text { First child ( } \mathrm{n}=268,30.8 \%) \\
\text { More than one child }(\mathrm{n}=602,69.2 \% \text { ) }\end{array}$ & $\begin{array}{l}32.5 \\
49.3\end{array}$ & $\begin{array}{l}67.5 \\
50.7\end{array}$ & $21.42 * * *$ \\
\hline $\begin{array}{l}\text { Time to clinic } \\
<30 \operatorname{Min}(\mathrm{n}=188,23.0 \%) \\
30-60 \quad(\mathrm{n}=357,43.6 \%) \\
>60-90 \quad(\mathrm{n}=118,14.4 \%) \\
>90 \operatorname{Min}(\mathrm{n}=156,19.0 \%)\end{array}$ & $\begin{array}{l}20.3 \\
39.3 \\
16.2 \\
24.2\end{array}$ & \begin{tabular}{|l}
25.1 \\
47.0 \\
13.0 \\
14.9
\end{tabular} & $15.27^{* *}$ \\
\hline $\begin{array}{l}\text { Time to hospital } \\
<30 \operatorname{Min}(\mathrm{n}=90,10.8 \%) \\
30-60 \quad(\mathrm{n}=206,24.6 \%) \\
>60-90(\mathrm{n}=143,17.1 \%) \\
>90 \operatorname{Min}(\mathrm{n}=397,47.5 \%)\end{array}$ & $\begin{array}{l}7.6 \\
25.5 \\
16.0 \\
50.9\end{array}$ & $\begin{array}{l}13.3 \\
24.0 \\
18.0 \\
44.8\end{array}$ & $8.53^{*}$ \\
\hline $\begin{array}{l}\text { Costs to clinic } \\
<5.00 \text { Rand }(\mathrm{n}=136,18.3 \%) \\
5-10.00 \quad(\mathrm{n}=381,51.3 \%) \\
>10.00 \text { Rand }(\mathrm{n}=226,30.4 \%)\end{array}$ & $\begin{array}{l}19.4 \\
54.8 \\
25.8\end{array}$ & $\begin{array}{l}17.4 \\
48.4 \\
34.1\end{array}$ & $6.10^{*}$ \\
\hline $\begin{array}{l}\text { Distance to hospital\# } \\
<35 \mathrm{~km}(\mathrm{n}=618,71 \%) \\
>35 \mathrm{~km}(\mathrm{n}=252,29 \%)\end{array}$ & $\begin{array}{l}60.9 \\
39.1\end{array}$ & \begin{tabular}{|l|}
79.0 \\
21.0
\end{tabular} & $34.06 * * *$ \\
\hline $\begin{array}{l}\text { Access to telephone } \\
\text { Yes }(\mathrm{n}=215,25.8 \%) \\
\text { No }(\mathrm{n}=619,74.2 \%)\end{array}$ & $\begin{array}{l}22.1 \\
77.9\end{array}$ & $\begin{array}{l}28.7 \\
71.3\end{array}$ & $4.71^{*}$ \\
\hline
\end{tabular}

${ }^{* * *} \mathrm{p}<.001,{ }^{* *} \mathrm{p}<.01,{ }^{*} \mathrm{p}<.05$; \# Pregnant women recruited from three clinic areas were on average less than $35 \mathrm{~km}$ (measured from the location of the clinic) and from two clinic areas on average more than $35 \mathrm{~km}$ away from the nearest hospital.
$44.1 \%$ at home (mostly without being assisted by a TBA). The finding that only a few $(0.6 \%)$ had delivered their last baby in a clinic could be explained by the fact that the primary health care clinics do not offer maternity services, only assist in case of emergency or deliver the first child when a woman has no experience (Peltzer, Mosala, Dorkenoo \& Gumede 2003). A study among TBAs in the same study area confirms that TBAs mostly assist pregnant.women if they cannot make it to the hospital, as emergency and not as a planned home delivery (Henda \& Peltzer, in print: 3). Cronje, Joubert, Chapman, Winnaar and $\operatorname{Bam}(1995: 1190)$ also found among rural women in the Free State that only in a minority home deliveries were attended by TBAs. The relatively high percentage $(44 \%)$ of home deliveries among these women in the rural Eastern Cape compares with twothirds home deliveries of women in a study in the Eastern Cape more than ten years ago (O'Mahony \& Steinberg 1995: 1168). Similarly, the mothers or mother-in-laws of the pregnant women studied indicated that two-thirds of their last born child was delivered at home. More recent studies seem to show a trend to increased health facility delivery, for example in a recent study among women in rural KwaZulu-Natal $77 \%$ had delivered in a health facility (Tsoka et al. 2003: 70).

This study found that the odds of reaching a health care facility increase by almost 3 fold if women stay nearby than those who stay far from the hospital ( $\mathrm{OR}=2.87$ ), also women who are more educated have 1.5 chance of accessing the 


\begin{tabular}{|c|c|c|c|c|}
\hline Variables & $\begin{array}{l}\text { Total } \\
(\%)\end{array}$ & $\begin{array}{l}\text { Home-based } n=384 \\
(\%)\end{array}$ & $\begin{array}{l}\text { Setting-based } n=486 \\
(\%)\end{array}$ & $\chi^{2}$ \\
\hline $\begin{array}{l}\text { Delivery option (for current pregnancy) } \\
\text { Home } \\
\text { Health facility }\end{array}$ & $\begin{array}{l}\mathrm{N}=870 \\
6.3 \\
93.7\end{array}$ & $\begin{array}{l}13.4 \\
86.6\end{array}$ & $\begin{array}{l}0.6 \\
99.4\end{array}$ & $59.49^{* * *}$ \\
\hline $\begin{array}{l}\text { Mother/mother-in-law delivered last } \\
\text { born in: } \\
\text { Home } \\
\text { Health facility }\end{array}$ & $\begin{array}{l}\mathrm{N}=581 \\
62.8 \\
37.2\end{array}$ & $\begin{array}{l}76.3 \\
23.7\end{array}$ & $\begin{array}{l}53.9 \\
46.1\end{array}$ & $30.01 * * *$ \\
\hline $\begin{array}{l}\text { Mother/mother-in-law wants daughter to } \\
\text { deliver baby in: } \\
\text { Home } \\
\text { Health facility }\end{array}$ & $\begin{array}{l}2.7 \\
97.3\end{array}$ & $\begin{array}{l}5.8 \\
94.2\end{array}$ & $\begin{array}{l}0.6 \\
99.4\end{array}$ & $13.68^{* * *}$ \\
\hline $\begin{array}{l}\text { Partner/husband wants wife to deliver in: } \\
\text { Home } \\
\text { Health facility }\end{array}$ & $\begin{array}{l}N=478 \\
2.9 \\
97.1\end{array}$ & $\begin{array}{l}5.3 \\
94.7\end{array}$ & $\begin{array}{l}1.1 \\
98.9\end{array}$ & $7.12^{* *}$ \\
\hline
\end{tabular}

$* * * \mathrm{p}<.001,{ }^{* *} \mathrm{p}<.01,{ }^{*} \mathrm{p}<.05$

health facility than the less educated women $(\mathrm{OR}=1.55)$, the odds of reaching a hospital is almost doubled if the pregnant women can afford traveling costs than those who have no money for traveling $(\mathrm{OR}=1.77)$, and unmarried women have a 1.5 more chance of getting to a health care facility than the married women $(\mathrm{OR}=1.58)$. Age, economic status (dwelling type), number of children, average travel time to nearest hospital and clinic, and access to telephone were not related to health facility delivery. In this study physical access to the nearest hospital (the only facility for maternity services) was difficult (from the four clinic areas under study the distances to the hospital ranged from $(20,25,35$ to 44$)$ $\mathrm{km}$ and were the most significant factor for low utilization of delivery services at this level. This is conforming to some other studies (Amooti-Kaguna \& Nuwaha 2000:203; Uyirwoth et al. 1996: 91 ), e.g. in Kenya utilisation of health facilities for maternity services was significantly influenced by the distance to health facility. Mothers living less than $5 \mathrm{~km}$ to a health facility utilised the services better than those living $5 \mathrm{~km}$ and beyond (Mwaniki, Kabiru \& Mbugua 2002:184). However, in this study shorter traveling time to the hospital was not significantly related to health facility delivery, suggesting that the underutilization of delivery services cannot be simply explained by geographical access to health care alone (Jahn, Dar Iang, Shah \& Diesfeld 2000:657). Tsoka et al. (2003:72) also found among women in rural KwaZulu-Natal, Duong et al. (2004:167) among rural Vietnamese women, Rasheed (1990:229) among rural Saudi Arabian women, and Celik and Hotchkiss (2000:1797) among Turkish women that high levels of maternal education were associated with health facility delivery. Indirect costs such as transportation was an important factor that affected the delivery option. Other studies also found that hidden costs could contribute to a low utilization of maternity services (Duong et al. 2004:167; Nahar \& Costello 1998:417; Uyirwoth et al. (1996: 91). Access to telephone was in this study not associated with health facility delivery and it could be questionable that improved access to telephones for emergency calls would have an impact of health facility delivery.

Being single was in this study associated with health facility delivery and maternal age but when age was controlled for in multivariate analysis it was no longer significant. So it appears that being a single mother was not seen as a barrier to health facility delivery but to home delivery, while among rural women in Vietnam childbirth was commonly perceived as the product of a marital relationship and a single mother could feel stigmatized or discriminated against by health workers or other people at a health setting (Duong et al. 2004:171) Contrary to the findings of this study, other studies, e.g. in Kenya (Mwaniki et al. 2002:184), Vietnam (Duong et al. 2004:171) and Saudi Arabia (Rasheed 1990:229) found that utilisation of health facilities for maternity services was significantly influenced by number of children in that, as number of children increased, utilisation of maternity services reduced.

Social factors appeared to contribute to the low utilization of maternity health services. Childbirth experiences of the mother or mother-inlaw greatly in terms of home delivery influenced the delivery choices of the pregnant women in this study. Having support from the mother-in-law was associated with home delivery. However, almost all pregnant women, their mothers or mother-in-laws and partners or husbands intended to deliver the current pregnancy in a health facility but only the pregnant women's intentions were significantly related with the past delivery option. Experience elsewhere has shown that most of these women intend to deliver at health facilities but cannot find transport when they go into labour at home (Tsoka et al. 2003:72). It appears that the attitudes of mothers or motherin-laws did not play a significant role in the delivery option in this study, while the influence of in-laws and extended family in rural Vietnam (Duong et al. 


\begin{tabular}{|c|c|c|c|c|}
\hline Variables & $\begin{array}{l}\text { Total } \\
(\%)\end{array}$ & $\begin{array}{l}\text { Home-based n=384 } \\
(\%)\end{array}$ & $\begin{array}{l}\text { Setting-based } \mathrm{n}=486 \\
(\%)\end{array}$ & $x^{2}$ \\
\hline $\begin{array}{l}\text { HIV knowledge\#(self) } \\
\text { Correct } \\
\text { Incorrect/not know }\end{array}$ & $\begin{array}{l}80.6 \\
19.4\end{array}$ & $\begin{array}{l}79.7 \\
20.3\end{array}$ & $\begin{array}{l}81.4 \\
18.6\end{array}$ & .39 \\
\hline $\begin{array}{l}\text { HIV knowledge\# (mother/in-law) } \\
\text { Correct } \\
\text { Incorrect/not know }\end{array}$ & $\begin{array}{l}71.2 \\
28.8\end{array}$ & $\begin{array}{l}73.8 \\
26.2\end{array}$ & $\begin{array}{l}69.4 \\
30.6\end{array}$ & 1.29 \\
\hline $\begin{array}{l}\text { HIV knowledge (partner/husband) } \\
\text { Correct } \\
\text { Incorrect/not know }\end{array}$ & $\begin{array}{l}70.7 \\
29.3\end{array}$ & $\begin{array}{l}74.1 \\
25.9\end{array}$ & $\begin{array}{l}68.2 \\
31.8\end{array}$ & 2.04 \\
\hline $\begin{array}{l}\text { Contact with HIV community worker } \\
\text { Yes } \\
\text { No }\end{array}$ & $\begin{array}{l}44.1 \\
55.9\end{array}$ & $\begin{array}{l}51.3 \\
48.7\end{array}$ & $\begin{array}{l}38.5 \\
61.5\end{array}$ & $14.06^{* *}$ \\
\hline $\begin{array}{l}\text { HIV testing (self) } \\
\text { Ever had test } \\
\text { Never had test }\end{array}$ & $\begin{array}{l}8.6 \\
91.4\end{array}$ & $\begin{array}{l}7.9 \\
92.1\end{array}$ & $\begin{array}{l}9.2 \\
90.8\end{array}$ & .43 \\
\hline $\begin{array}{l}\text { HIV testing (partner/husband) } \\
\text { Ever tested } \\
\text { Never tested }\end{array}$ & $\begin{array}{l}13.4 \\
86.6\end{array}$ & $\begin{array}{l}13.3 \\
86.7\end{array}$ & $\begin{array}{l}13.5 \\
86.5\end{array}$ & .00 \\
\hline $\begin{array}{l}\text { Mother/in-law encourages HIV testing } \\
\text { of daughter } \\
\text { Yes } \\
\text { No }\end{array}$ & $\begin{array}{l}98.5 \\
1.5\end{array}$ & $\begin{array}{l}98.4 \\
1.6\end{array}$ & $\begin{array}{l}98.6 \\
1.4\end{array}$ & .02 \\
\hline $\begin{array}{l}\text { Partner/husband encourages HIV testing } \\
\text { of wife } \\
\text { Yes } \\
\text { No }\end{array}$ & $\begin{array}{l}95.3 \\
4.7\end{array}$ & $\begin{array}{l}96.1 \\
3.9\end{array}$ & $\begin{array}{l}94.7 \\
5.3\end{array}$ & .50 \\
\hline
\end{tabular}

2005:172) and social influence from the spouse among Ugandan women (Amooti-Kaguna \& Nuwaha 2000:203) seemed to have strong effects on the delivery options.

The majority of the pregnant women, their mothers or mother-in-laws and partners or husbands knew that a pregnant woman infected with HIV or AIDS can transmit the virus to her unborn child, but only $9 \%$ of the pregnant women and $13 \%$ of their partners or husbands ever had an HIV test. Further, almost all mothers or mother-in-laws and partners or husbands of the pregnant women would, however, encourage their daughter or wife to have an HIV test done. HIV knowledge, HIV testing behaviour and attitudes were found to be not associated with the delivery option (home-based or setting-based).

\section{Conclusion and recommendations}

In order to make delivery safer, there is a need to improve access to maternity services by reducing the distance to maternity facilities, increase the number of skilled personnel, provide emergency transport (those that come from far, arrangements for "waiting mothers" accommodation near the point of delivery in the absence of suitable or reliable transport should be made), train TBAs and equip them with delivery kits in case of emergency delivery, and health and social improvements such as increased female health education.

Primary care providers have a strong influence over women's perceptions of antenatal care and are in a good position to provide appropriate educational messages. Health promotion strategies should be based on exploring patients explanatory models of health in pregnancy and childbirth.

\section{Limitations}

The quality of maternity services in a health facility and at home (with or without a TBA) and prenatal services was not assessed (Duong et al. 2004: 167) in this study but can greatly contribute to delivery choices. Data were collected from the self-report of respondents. Such 
information could incur recall bias, especially with regard to travelling time and costs of transportation to the nearest health facility.

\section{Acknowledgements}

We would like to thank the Ford Foundation for financial support, and the pregnant women, mothers, mothers-inlaw, husbands and partners who participated in this study.

\section{References}

AMOOTI-KAGUNA, B \& NUWAHA, F 2000: Factors influencing choice of delivery sites in Rakai district of Uganda. Social Science \& Medicine. 50: 203-213.

CELIK, Y \& HOTCHKISS, DR 2000: The socio-economic determinants of maternal health care utilization in Turkey. Social Science and Medicine. 50: 1797-1806.

CRONJE, HS; JOUBERT, G; CHAPMAN, RD; DE WINNAAR, B \& BAM RH 1995: Utilisation of maternity services by black women in rural and urban areas of the Orange Free State. South African Medical Journal, 85(11): 1190-1191.

DUONG, DV; BINNS, CW \& LEE, AH 2004: Utilization of delivery services at the primary health care level in rural Vietnam. Social Science \& Medicine. 70(2): 163-174.

HENDA, $N$ \& PELTZER, $K$ in print: Traditional birth attendants in the Eastern Cape, South Africa: characteristics, role and HIV/AIDS. Journal of Medical Anthropologv and Transcultural Psychiatry.

JAHN, A; DAR IANG, M; SHAH, U \& DIESFELD, HJ 2000: Maternity care in rural Nepal: a health service analysis. Tropical Medicine and International Health, 5(9): 657-665.

MAHLALELA, X; ROHDE, J; MEIDANY, F; HUTCHINSON, P \&BENNETT, J 2001: Primary Health Care in the Eastern Cape Province, 1997 2000. Bisho: Eastern Cape Department of Health, South Africa.

MCCOY, D 1996: Free health care for pregnant women and children under six in South Africa: an impact assessment. Health Systems Trust. 6: 5-6.
MILIS, S \& BERTRAND,JT 2005: Use of health professionals for obstetric care in northern Ghana. Studies in Family Planning. 36(1): 45-56.

MOORE, M. 2003: A behavior change perspective on integrating PMTCT and safe motherhood programs: a discussion paper. Washington, D.C.: The Change Project: AED/The Manoff Group.

MUNRO, BH \& PAGE, EB 1993: Statistical methods for health care research. Philadelphia: J.B. Lippincott.

MWANIKI, PK; KABIRU, EW \& MBUGUA, GG 2002: Utilisation of antenatal and maternity services by mothers seeking child welfare services in Mbeere District, Eastern Province, Kenya. East African Medical Journal. 79(4): 184-187.

NAHAR, S \& COSTELLO, A 1998: The hidden cost of 'free' maternity care in Dhaka, Bangladesh. Health Policy Plan. 13(4): 417-422.

O'MAHONY,D \& STEINBERG,M 1995: A population-based survey of obstetric practices among rural women in the Bizana district, Transkei. South African Medical Joumal, 85(11): 1168-1171.

PELTZER, K; MOSALA, T; DORKENOO, E \& GUMEDE, T 2003: Health facility baseline report on Preventing Mother-To-Child Transmission (PMTCT) in region E, Eastern Cape (Report). Johannesburg: Ford Foundation.

PELTZER, K; SKINNER,D; MFECANE, S; SHISANA, O; NQEKETO, A \& MOSALA, T 2005: Factors influencing the utilization of prevention of motherto-child-transmission (PMTCT) services by pregnant women in the Eastern Cape South Africa. Health SA Gesondheid, 10(1): $26-41$.

RASHEED, P 1990: A multifactorial study of birth place options: improving health care delivery in Saudi Arabia. International Journal of Gynaecology \& Obstetrics. 33(3): 229-234.

RSA NATIONAL TREASURY 2001: RSA National Intergovernmental Fiscal Review 2001. Cape Town: Formset Printers.

TSOKA, JM; SUEUR, DLE \& SHARP,
BL 2003: Maternal health service utilization in Ubombo district. South African Journal of Obstetrics \& Gvnaecology. 9(3): 70-74.

UYIRWOTH, GP; ITSWENG, MD; MPAI,S; NCHABELENG,E\& NKOANE, H 1996: Obstetrics service utilisation by the community in Lebowa, northern Transvaal. East African Medical Journal. 73(2): 91-94. 